\title{
THE SLOW AND HIDDEN ROAD TO SERFDOM
}

\author{
PETER BERNHOLZ*
}

Fecha de recepción: 15 de marzo de 2013

Fecha de aceptación: 25 de junio de 2013

It is seldom that liberty of any kind is lost all at once.

DAvid Hume

\section{I \\ FREEDOM AND THE RULE OF LAW}

Without the rule of law limiting the discretionary powers of government agencies, but also of other organizations and individuals no individual freedom is possible. If government representatives or private persons can order at their discretion individuals to behave in certain ways, no individual liberty is guaranteed. As Immanuel Kant expressed it «man is free if he needs to obey no person but solely the law.» And even if individuals are only obliged to follow the law, their freedom is always threatened if these laws can be changed arbitrarily by any individuals or government authorities. This is even true for democracies in which duly elected parliamentary majorities (that is minorities) are allowed to introduce new laws or change old ones relating to any sphere of human activities. The problem has been clearly stated by Alexis de Tocqueville (1945, vol. I, p. 270):

\footnotetext{
* Prof. Em. Dr. Peter Bernholz, Center for Economics and Business (WWZ). Universitaet Basel,Peter Merian Weg 6, Postfach CH-4002 Basel, Switzerland. This paper has already been published as a little bit shorter version in CESifo Forum, vol. 14, n. ${ }^{2}$, Summer 2013, pp. 61-74. I am grateful to Christoph Bauer for helpful critical comments.
} 
When I see that the right and the means of absolute command are conferred on any power whatever, be it called a people or a king, an aristocracy or a democracy, a monarchy or a republic, I say there is the germ of tyranny, and I seek to live elsewhere, under other laws.

Similar ideas are expressed by Friedrich v. Hayek (1944, p. 62):

The Rule of Law thus implies limits to the scope of legislation: it restricts it to the kind of general rules known as formal law, and excludes legislation either directly aimed at particular people, or at enabling anybody to use the coercive power of the state for the purpose of such discrimination.

Nobody is allowed to be punished except on the basis of a law which existed before the time of his action. All individual activities which are not forbidden are allowed. In such a system of a free society individuals can calculate the consequences of their decisions in advance and conclude agreements with others which are not in contradiction to the legal framework.

But as pointed out by de Tocqueville, this is not sufficient. The majority even in a democracy (including majorities in referendums and popular initiatives) should not be permitted to pass general laws forbidding everybody to become fat or to smoke, as long as he does not damage others by doing so. And nobody should be forced to take up sporting activities to preserve her health.

But though such regulations by patriarchal states are dangerous they look trivial compared to problems in other countries. Many in the West hoped that the so-called Arabian revolutions in Tunisia, Egypt and Libya in the first decade of the $21^{\text {st }}$ century would lead to democracies with the rule of law. But they overlooked that majority decisions can be an existential danger for minorities suppressed by them. And it was obvious from the beginning that more or less radical Muslims constituted a majority of the population in these countries. So the Muslim Brotherhood won a majority in the Egyptian parliamentary elections and Tunisia saw a similar outcome. But now the secular and Christian minorities are rightly concerned that they may be subjected to general laws 
following the commands of the Sharia, and new protesting demonstrations are raging in the streets of Cairo and Tunis.

It is important not to confuse the rule of law with legality. Even an order which is only directed to an individual or specific group of persons can be put into a legal form.

But why is freedom so important? Are there not other aims like justice, equality and safety of people which are as or even more important? And how can freedom and the rule of law be secured, when at the same time an institutional framework has to be provided by the state? Let us first shortly discuss the last of these questions. As stressed by Thomas Hobbes in his Leviathan it is impossible to fully remove the problem of unlimited discretionary rule whenever there exists a sovereign or state with a monopoly of power in the form of an army or police. And anarchy is usually even worse than despotism. But since the publication of Hobbes' book several institutional inventions and proposals have been made by John Locke and others of how at least partly to solve this problem. As an important example let me quote James Madison (The Federalist N.․47):

The accumulation of all powers, legislative, executive and judiciary, in the same hands, whether of one, a few, or many, and whether hereditary, self-appointed, or elective, may justly be pronounced the very definition of tyranny. (The Federalist, p. 313).

Thus Madison proposes a separation of powers into the legislative, the executive and the judicial branches of government, a proposal which found its application in the constitution of the United States. The executive branch has only the right to implement the laws passed by the legislative branch. The judiciary has to check whether the laws are executed according to their meaning and consistent with the constitutional rules. It has to do so even at the request of any citizen, group or member state. Besides the separation of powers federalism and direct democracy have been important measures to limit the abuse of government power.

But even all these institutional innovations are admittedly still limited in their effectiveness to secure individual freedom 
and to check the power of rulers. Thus the Supreme Court of the USA has even itself been instrumental in extending the domain of the central government beyond the limits foreseen in the American Constitution. And when the Swiss largely accepted the American example for their own constitution in 1848 they did not want to grant their highest court the right to check whether the Swiss Federal Constitution were violated by federal laws, referenda or initiatives. For they thought it unacceptable that the court might decide against a popular majority. But this «solution» had also its disadvantages as shown by several cases in which a clear violation of the federal constitution by the government occurred.

It follows that even the best institutions presently available cannot prevent the loss of individual freedom in the long run. As a consequence people have to be made aware again and again of dangerous developments in the hope to bring about a turnaround. In subsequent chapters we are going to describe developments that have steadily eroded individual freedom over the last decades. Hayek warned in his Road to Serfdom against the dangers threatening liberty mainly because of the vain hopes set at that time into government planning of the economy. Meanwhile the so-called planned economies have clearly demonstrated their inferiority not only in supplying goods and services but also because of their despotic suppression of freedom and human dignity. The collapse of the communist system in 1989 has not come about without grave reasons. Systems with mostly free markets, rather safe private property rights, relatively stable money and freedom of contract between individuals, business firms and organizations have proved far superior to any attempt of collective planning and property. But other, more subtle obnoxious developments are again threatening freedom, human dignity and well-being. To them we propose to draw attention on the following pages. 


\section{II THE SHRINKING SHARE OF DISPOSABLE PRIVATE INCOME}

What has always made the state a hell on earth has been precisely that man has tried to make it his heaven.

Friedrich Hölderlin (1946, 1. Buch, 7. Brief)

One of the least felt developments during the last decades has been the shrinking share of the income earned by private individuals which they are able to spend at their own discretion. This means that an increasing part of their gross incomes has to be paid in the form of taxes or other obligatory contributions, imposed by government law or decree. The latter comprise socalled social security premiums, like those financing unemployment contributions and old age pension systems. In all these cases not the earners but collective bodies decide on the use of the collected part of their incomes.

Concerning these developments two questions pose themselves: First, why have they be accepted without much resistance even in democracies? And even in those allowing popular referendums and initiatives like Switzerland? Second, are they and why are they dangerous for individual freedom? To answer these questions we have first to look at the facts.

As shown for five countries in Figure 1 the share of government in Gross Domestic Product (GDP), that is in the values of all goods and services produced, has risen inexorably over the last century (see also Tanzi and Schuknecht, 2000). And this is true for about all developed countries, even for Switzerland in spite of its traits of direct democracy. Why has this been tolerated by the population? True, Germany and Japan were no democracies for part of the period considered. And it is thus not surprising that the graph is showing a first maximum around 1938 because of the rearmament for World War II. But the increase of the share taken by governments resumes during the 60 years after 1950 . No end of this development can be expected presently.

Moreover, it is most disturbing that the rising government expenditures is not only financed by an increasing burden of 


\section{FIGURE 1}

\section{DEVELOPMENT OF SHARE OF GOVERNMENT EXPENDITURES IN GDP, 1913-2010}

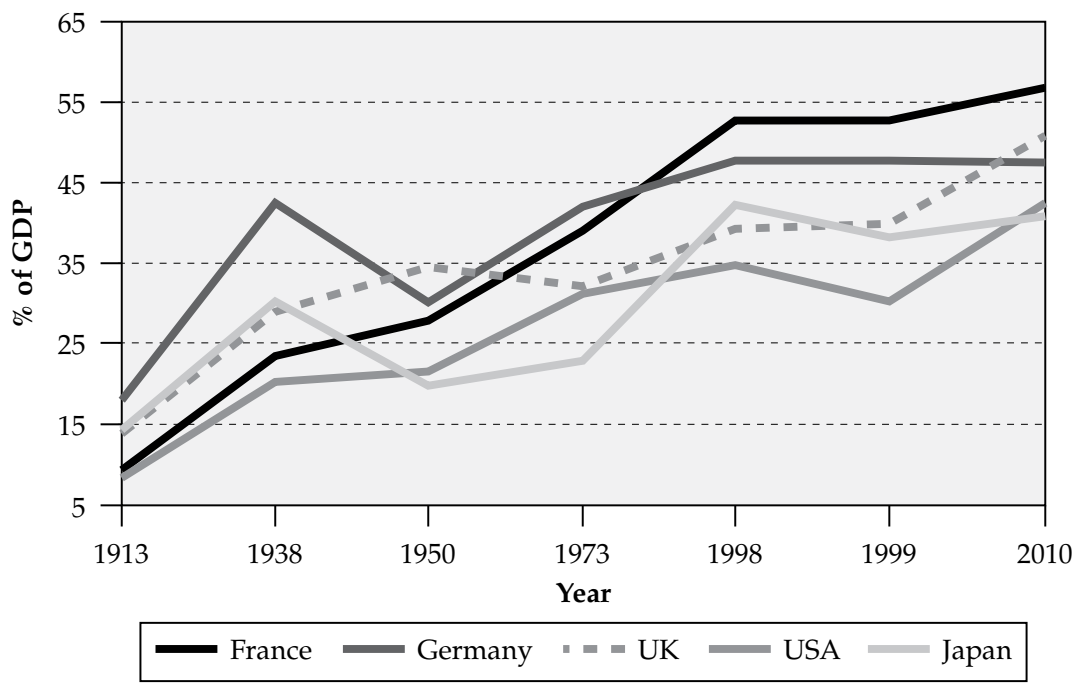

Sources: For dates until 1999: Maddison, Angus (2001): The World Economy. Paris: OECD: Development Centre Studies. Table 3-9, p. 135; OECD Economic Outlook, Paris: Several numbers until May 2012.

taxes and other obligatory contributions of the population, but also by financing government deficits by borrowing (Figure 2). In fact, the official figures given are only the explicit debts of governments. If their promises relating for instance to future pensions in an age of a population with ever rising life expectancies and low birth rates are taken into account, the implied government debts are much higher. Presently, except for massive further tax increases or a substantial reduction of outlays these debts can only be reduced either by government bankruptcies, inflation or both.

Given that the growing share of government expenditures in GDP has been steadily extending the power of rulers and diminishing the relative freedom of individuals, we have to ask ourselves why such a development is accepted by the population in democracies, in which voters have still the power to remove the rulers. Here several explanations come to mind. First, voters 
FIGURE 2

DEFICITS AND DEBTS OF DEVELOPED COUNTRIES 2011 (IN \% OF GDP)

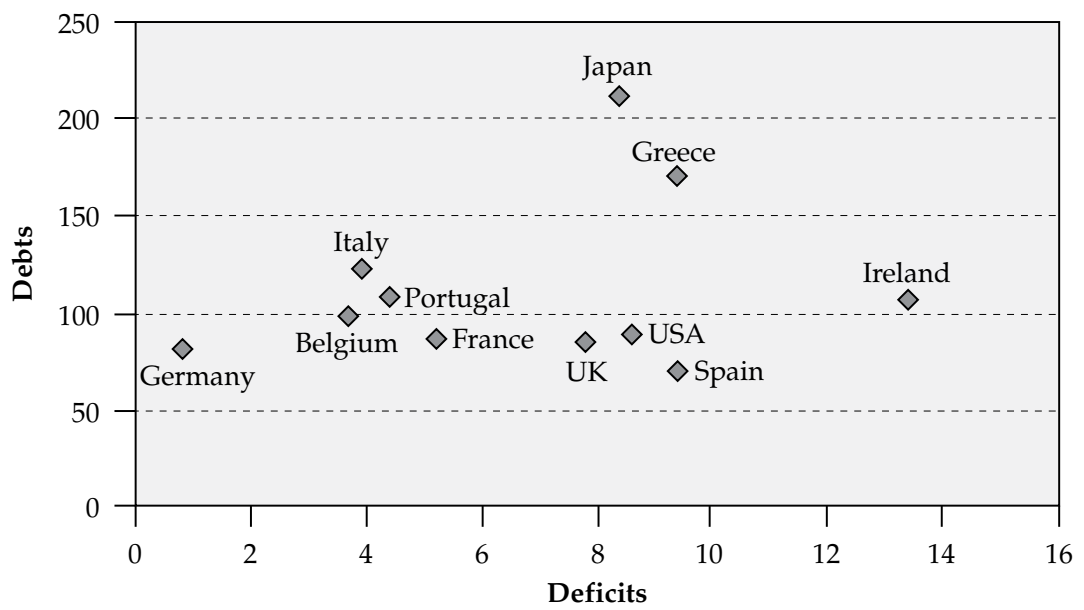

Source: European Central Bank: Monthly Reports, January 2013.

are uninformed for rational reasons. Since their vote is only one among millions, it would be irrational for them to inform themselves about matters which are not of immediate concern to themselves, namely their disposable incomes, their job security and some major expenditures like those on housing and cars. They may also feel some sympathy for the similar situation of near relatives and friends. Second, the government is distributing the tax burden in a way that only a minority of the population has to carry most of it. Third, to let the situation look better the governments prefer to incur debts instead of raising taxes further, and also to make uncovered promises for the future. Finally, and most importantly, the economy which is still mainly organized along the lines of free markets, has been able until now to increase GDP per capita in a way still allowing a growth of real private consumption in spite of an ever higher share of government expenditures (Figure 3).

As can be seen, private people have been able to increase their real expenditures in developed countries all the time since 1967 in spite of growing tax burdens. The surge in US figures after 1997 
FIGURE 3

DEVELOPMENT OF REAL PRIVATE EXPENDITURES, 1967-2010

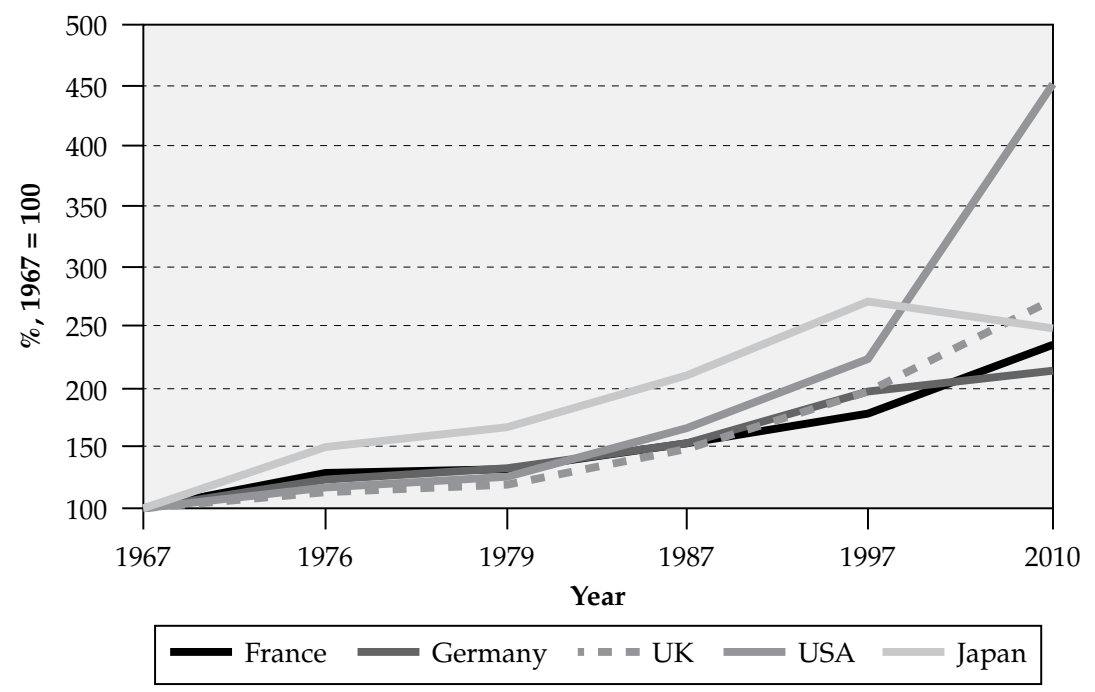

Source: OECD Economic Outlook. Paris: Several numbers until May 2012.

is due to ever higher private indebtedness, one of the main reasons for the bursting of the bubble in property prices in 2007. This growth rate was obviously not maintainable. In the decades before 1967 a similar growth of real private expenditures has occurred, except during the two World Wars and the Great Depression. Only Japan has seen a fall of real private expenditures since 1997. This is, of course, a warning. Indeed, there exist many empirical studies showing that the rate of growth of GDP diminishes with a growing share of government expenditures as well as debts at least beyond a certain threshold (Bergh and Karlsson, 2010; Bernholz, 1986; Romer and Romer, 2010; Weede 1991) and its debts rising beyond certain levels. Concerning the latter Reinhart and Rogoff (2011, p. 33; see also Baum, Westphal and Rother, 2012) conclude after having studied the experience of 44 countries over two centuries:

Our main finding is that across both advanced countries and emerging markets, high debt/GDP levels ( 90 percent and above) are associated with notably lower growth outcomes. Much lower 
levels of external debt/GDP (60 percent) are associated with adverse outcomes for emerging- market growth.

A final reason for the complacency of the population in democracies with the rising share of government in GDP has to do with the way additional revenues are spent. The greater part of the growth of the tax burden and expenditures has been used for transfers or redistribution. In Germany the upper $40 \%$ of the population paid $89,3 \%$ of income taxes in 2011, and the up-most $10 \% 54,6 \%$, whereas the majority was bearing only a negligible part (IW 2012, p. 67). Also, the greatest part of the redistribution is brought about by progressive income taxes, though there exists empirical evidence that just these taxes together with those on firms are most detrimental to economic growth (Arnold ,2008). Moreover, the redistribution of burdens is also pronounced in the old age pension systems, for unemployment benefits and support for health expenditures of the poorer segments of the population. Even in the USA, which are lagging the European welfare states, the share of the richest $1 \%$ in paying US federal taxes has risen from 14,2 to 27,7 \% from 1980 to 2005 (Lipford and Yandle 2012, p. 522). Now, since the wealthy persons bearing the burden of this redistribution form only a minority, they can easily be outvoted. Also, there exists a bias in voting outcomes because employees of the government will always vote against any reduction of government outlays because they are afraid to receive lower incomes or to be fired.

Moreover, many may argue that it is only an act of «social justice» that the rich are forced, if they are not willing, to help the poorer part of their compatriots to afford a decent life, to have access to adequate health services and to enjoy their old age without suffering from poverty. Is it not a great progress that all citizens are secured against unemployment and bad health? And consequently, is it not a blessing, that government expenditures are growing more strongly than GDP to provide all these benefits? And do not even wealthy people wholeheartedly agree with this handling of public affairs?

Unfortunately the just sketched picture is grossly misleading, not only concerning individual freedom but also for the long-term 
economic outlook. As already mentioned, growing tax burdens and government debts beyond certain levels, levels which have long been reached in welfare states, stifle in time the efficiency and the innovative capacity of the relatively shrinking free market economy, so that the real economy will no longer be able to allow a better life for most citizens in the future. Too extended welfare benefits also attract immigrants with lower capabilities and motivation to work, a fact which is also detrimental to economic development (Sinn, 2004, p. 423).

The same negative influences are exerted if the growth of welfare expenditures leads to a relative shrinking of those for the educational system.

Wrong and excessive welfare policies have already ruined more than one state in history. A prominent example is Argentina, the fourth richest country in the world in 1930, which was led by wrong policies to become an under-developing country culminating in hyperinflation in the early 1990s. Another example is Uruguay which took a similar path (without hyperinflation, but civil war instead). President Chavez has seemingly led Venezuela into the same direction until his death in 2013. A counterexample is provided by Sweden, which was able to return to higher economic growth by reducing the share of government in GDP from $67 \%$ in 1993 to $49 \%$ in 2012. At the same time it succeeded to reduce through the corresponding drastic reforms some tax rates and, moreover, the debts of the state from 70 t0 $37 \%$ of GDP until 2012 (Economist 2013: 3).

It should also be a warning that in the nations of the former Communist Bloc, where the state dominated the whole so-called planned economy, economic progress was negligible and an incredible suffering and suppression of the population took place. Already in 1971 the well-known Hungarian economist Janos Kornai asked why about all revolutionary new products had been invented and introduced in Western market economies during the last fifty years (Kornai 1971, pp. $271 \mathrm{ff}$.).

And indeed, economic freedom of individuals competing in markets is a necessary condition for furthering invention, innovation and efficiency (Weede, 2012). Individuals in and out of firms or organizations are lured not only by their own curiosity, 
but also by possible profits to invent, to introduce and to sell new products and services wanted in the market. Moreover, if business firms do not innovate, they will soon be driven into bankruptcy by their more successful competitors. And inventors can borrow money to develop their ideas if they can convince creditors of their value. Also, if they are not able or willing to become entrepreneurs themselves they are able to sell their inventions. All this presupposes, of course, free markets, safe property rights, relatively stable money and not too high taxes. But the motivation to take corresponding efforts and let children enjoy an adequate education is weakened the more, the less of the fruits of their work people can expect to keep. «Economic freedom» besides a stable and rational institutional framework is thus a prerequisite for efficient and innovative developments. It is not by chance that all countries introducing free market institutions like many Asian countries including China are now well on a path of economic development. Indeed, the success of market economies requiring at least economic freedom are the best allies of individual liberty, though the latter may not yet extend to political freedom with safe human rights. And one should never forget that a consequence of economic growth has also been longer education, lower child mortality and rising life-expectancy.

But what are the consequences of the rising share of the state sketched above for our «free» societies? Even the "patriarchal caring» of the government for our health, old age pensions and unemployment benefits increases our dependency on the state. How far are citizens prepared to vote against the plans of a government to ever extend its domain and power, who are dependent for the payment of their health expenses, their unemployment and old age retirement incomes on the state? But even here differences caused by the institutional settings remain. For the dependence on government is certainly higher, if all these payments flow from a central state like for instance in France than if they are obligatory but provided by different private and decentralized public agencies, like the cantons in Switzerland. Anyhow, it is important to recall that the major part of the increase in government expenditures during the last decades has been caused by the extension of such patriarchal «insurance» systems. 
Note also that these systems, though they are often called «insurances», are not really proper insurances, since they are usually combined with substantive redistribution. In Germany this is the case because part of the expenses are financed out of the progressive income tax; in Switzerland the basic old age pension system AHV (a pay-as-you-go system) is managed by the central government, and the higher incomes have to pay the highest contributions, though the pensions after retirement are capped to a maximal amount for everybody. In spite of these facts Social Democrats in Switzerland are vehemently fighting any increase of the retirement age (for instance for women to 65 years), and have instead started a popular initiative for a national inheritance tax of $20 \%$ on all fortunes of two million Swiss francs or more to finance the AHV for some time; and this though some cantons have already heavy wealth and a few inheritance taxes In Britain health expenses are fully covered out of ordinary tax revenues.

A second disadvantage for a free society of these patriarchal welfare systems are that individuals are not allowed to opt out and to care for themselves, and to manage the savings according to their own discretion, an option which might in many cases lead to better results than those reached by the obligatory pension funds. And though it has to be admitted that many people have not the strength and the capability to built up adequate savings and to manage them, it still remains true that they are even less urged to learn these skills because of patriarchal care. The good shepherd is looking after his sheep who are kept in ignorance. As the British sociologist Herbert Spencer expressed it drastically (1891, p. 354): The ultimate result of shielding men from the effects of folly, is to fill the world with fools.

Moreover, it remains a question whether the shepherd is really fulfilling his task. It is revealing that in the USA the Federal Government is presently covering part of its budget deficit by «borrowing» from the social security funds (Figure 4). As can be seen, nearly $25 \%$ of the Federal debt is held as a claim by federal pension funds. How safe are these «assets»? And in countries like Germany the old age pensions are «covered» mostly by a pay-asyou-go system in which current pensions are paid out of present contributions of the working population. This system is threatened 
FiguRE 4

CREDITORS OF THE US FEDERAL DEBT OF \$ 16,027 BILLION (2012)

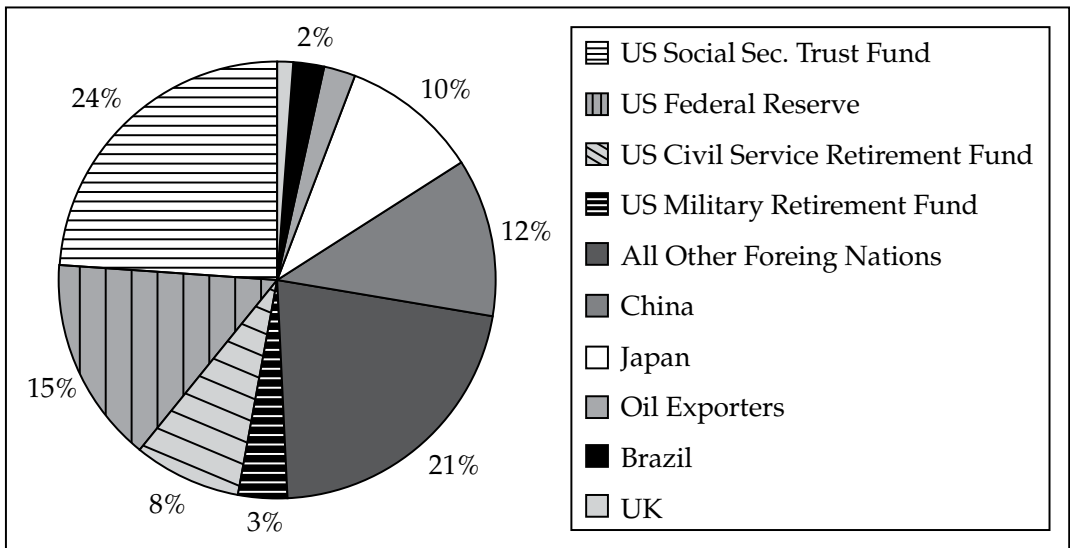

Source: Congressional Bureau of the Budget.

by the low birth rate nowadays leading to a shrinking population and working force. This means that the promises for future pensions are not covered by the present rates of contributions and thus imply an implicit debt of the government not contained in the official debt figures. Though it has to be admitted that some governments like Germany have taken several reform steps like raising the pension age, reducing the promised public payments to retired people and asking still employed people to save privately for their old age, these measures are still not sufficient and are absent in several other nations (Börsch-Supan, 2012).

Let me sum up. The creeping expansion of government expenditures as a share of GDP has been decreasing relative freedom of individuals over decades without being noticed by the majority. The reason has been the still possible rise of private real expenditures, putting most of the burden on a minority of tax payers and the forced care and redistribution by the welfare state by providing unemployment benefits, health payments and old age pension systems.

This has led to a rising dependency of the broad majority of the population on the government which is probably eroding the 
independence of citizens in their voting decisions. Moreover, paradoxically they are asked to decide as voters questions which they are deemed to be unable to decide for themselves privately. Individuals are no longer educated to save and to invest for their own future. They are cared for by the good will of their shepherds. Moreover, the bureaucracy handling the welfare state is costly and swallows a sizable part of resources available for this purpose. Also, politicians are tempted to hide the costs of the system by incurring debts and making uncovered promises for the future. Finally, empirical studies and the facts presented above suggest that a further development of the welfare state will bring about a crisis because the relatively shrinking market economy and the vanishing motivation of individuals to work efficiently, to invent and to innovate will no longer be able to carry the rising burden of government «care».

III

THE EVER-INCREASING BURDEN OF REGULATIONS DOMINATING INDIVIDUAL LIFE

It is more difficult to find meaningful measures for the growing flood of regulations limiting the freedom of individuals and the creative activities of business firms. As a first possible measure we may select the share of people employed by governments or government agencies in total employment (Figure 5). This share has been increasing steadily until the 1970s, but has since fallen or stabilized in three of the five countries considered. It had, however, already risen strongly before the 1960s. The German figures were, for instance, 3,45 and 5,53\% for 1933 and 1950. Thus the change since 1970 is probably the result of economic problems stemming from the rising share. That the share increased further in France since 1970 may be one of the reasons that this country is presently (2013) lagging economically behind Germany and suffering from a higher unemployment rate..

Other indicators of government regulations are more disturbing, especially the rising flood of new laws and executive orders. In an answer to an inquiry of Adriano Cavadini, member of the 
FIGURE 5

SHARE OF PEOPLE EMPLOYED BY GOVERNMENT AND GOVERNMENT AGENCIES IN TOTAL EMPLOYMENT, 1960-2005

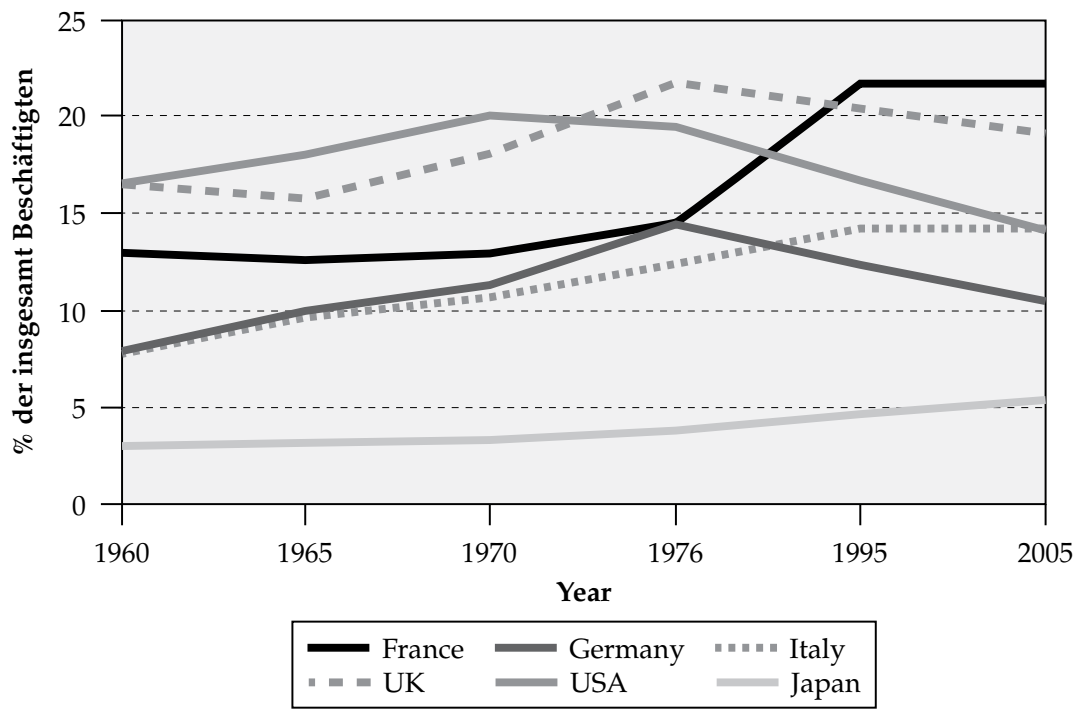

Source: OECD (2009): Government at a Glance; OECD (1978): Public Expenditure Trends.

lower house of the Swiss parliament (the Nationalrat) of March 21, 1997 the Swiss Federal Government (the Bundesrat) admitted on June 16, 1997:

The increasing production of legal norms, even if the underlying reasons may be understandable, is leading to a feeling of citizens and business firms that they have lost the control of the legal framework within which they have to move, and are facing unsurmountable obstacles. The ever increasing change of the law and its rising differentiation require such a capability to adapt and such expenditures which not all can afford. This can especially lead to problems for small and medium-sized firms and lower private initiative (my translation).

For the USA a prominent legal scholar (Epstein 1995, IX, 14) complained: 
There is too much law and too many lawyers....We try to solve more and more problems through legal intervention, and fewer through voluntary accommodation and informal practices.

And indeed, the rising flood of new laws and executive orders is appalling, which can be demonstrated by just looking at a few other countries (Figures 6 and 7). According to Sweet \& Maxwell's Westlaw UK and Lawtel online legal information the annual average legislation introduced amounted to 1724 laws under Margaret Thatcher, 2402 under John Major and 2663 under Tony Blair as Prime Ministers.

A similar picture could be shown for other developed nations. According to a report by the Mercatus Center (George Mason University, Fairfax, Virginia) of October 18, 2012, the number of instances of the words "may not», «must», "prohibited» and «required» and «shall» in US Federal Regulatory Restrictions rose steadily from 834949 in 1997 to 1001153 in 2010. This means an increase of 12808 per year, whereas the average annual growth of regulations had been only 4013 per year during the preceding

Figure 6

NUMBER OF NEW LAWS PASSED IN THE UK

BY THE PARLIAMENT IN CERTAIN YEARS, 1990-2010

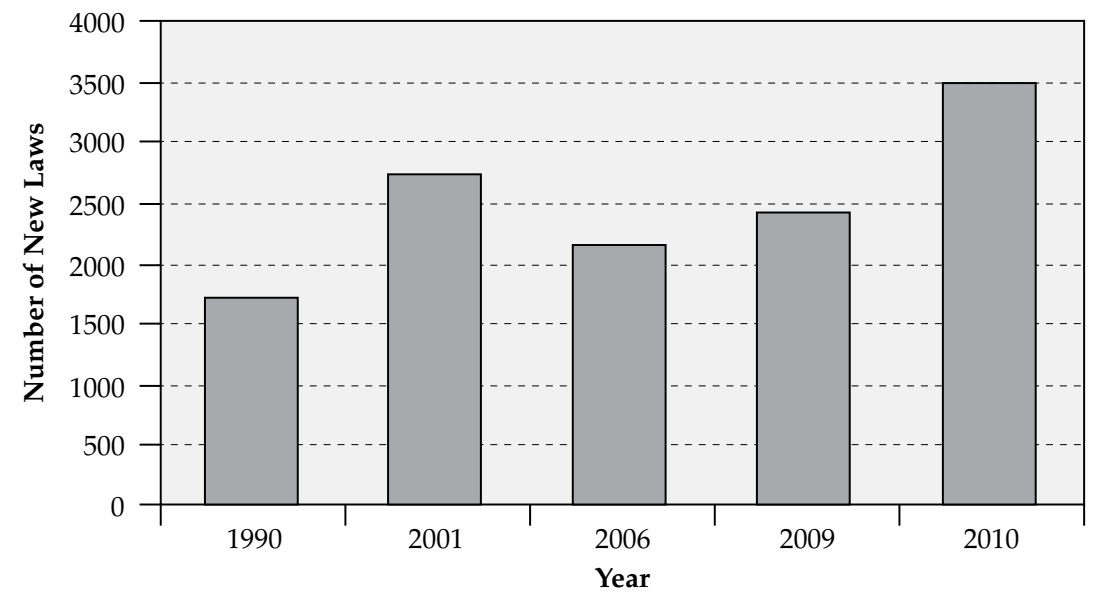

Source: BBC News: UK Politics: Record number of new laws made in 2010. May 27, 2011. 
FIGURE 7

PAGES OF THE NEW LAWS PASSED BY THE AUSTRALIAN PARLIAMENT IN CERTAIN YEARS, 1907-2010

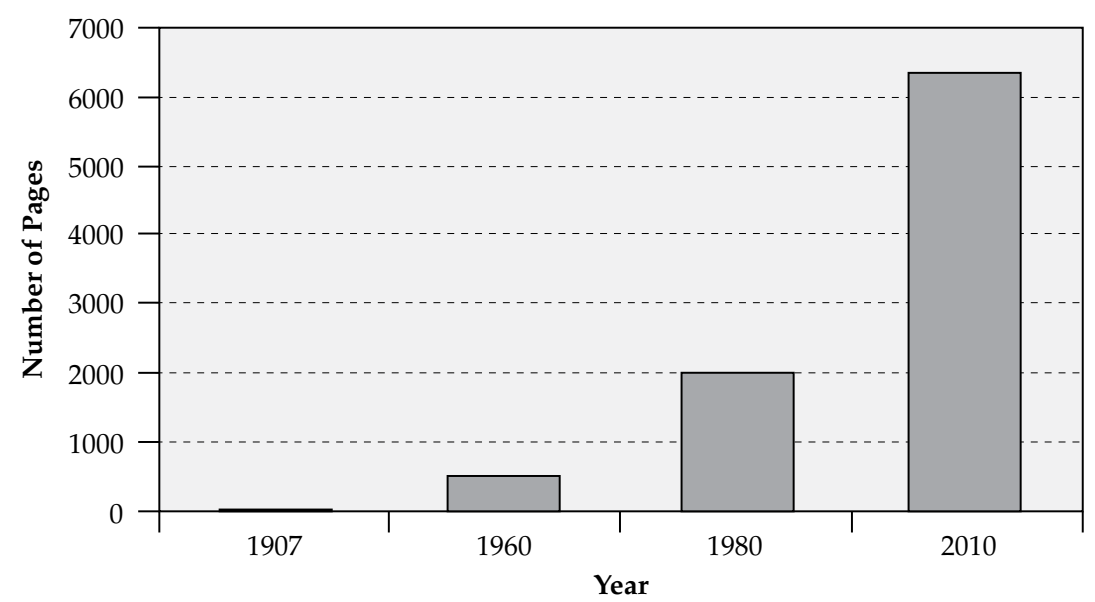

Source: Chris Berg: Micromanagement in the regulatory state. Drum Opinion. The

Drum on ABC News 24, January 25, 2011.

208 years since 1789. And in a testimony of March 15, 2013, to a committee of the US House of Representatives James L. Gattuso (2013) explained:

During President Obama's first four years in office, over 130 major rules increasing regulatory burdens (roughly defined as costing $\$ 100$ million or more each year) were adopted by agencies, ... By comparison, about 50 such rules ...were imposed during George W. Bush's first term.

One can easily imagine what this means for over-burdened citizens and business firms. The rule of law is severely weakened, since individuals are no longer able to even know all the laws, orders and regulations through which their freedom of taking decisions is severely restricted. At the same time they are often in danger of committing «criminal» acts without even being aware of them. And even if small firms could shoulder the time spent and the rising expenses of complying to laws, orders and regulations, their resources have to be misdirected and are no longer 
available for innovation. And ever fewer citizens will be prepared to found and to lead new enterprises.

Part of the increasing flood of laws and regulations is certainly caused by the increasing complexity caused by an increase of the population and by economic development. Whereas the former is probably too small in developed nations to be of great influence, the latter may be much more important. Economic growth is largely carried with the introduction of ever new products, the production, transportation and use of which may involve new risks for safety and health. The number of accidents increases with the number of cars used, new chemicals and pharmaceutical drugs may be dangerous to produce or to use, or may be connected with risky side-effects. The volume of waste-products has been increasing with industrial production as has air and water pollution. More and more plant and animal species are threatened by extinction. Thus new laws and regulations as well as market-imitating mechanisms may be required to limit or reduce these dangers and risks. Speed limits for driving and safety rules for producing chemicals may be necessary. Agencies have to be created to control the effects and side-effects of drugs before they are admitted for production and general application.

But how important are these factors in explaining the rising flood of laws and regulations? One possible but crude approach to measure this influence would be to analyze whether the growth of the number of laws and regulations has been smaller or greater than that of GDP. If we do this for the figures used in Figures 6 and 7 by dividing them by the respective development of real GDP we get the result that the new figures are still growing substantially. This means that the rising complexity of life explains only a part of the rising number of laws and regulations.

There exists also some direct evidence for an over-extension of the regulation for chemicals in the European Union (EU). The new REACH legislation (Regulation, Evaluation, Authorization and Registration of Chemicals) created the new agency ECHA (European Chemical Agency) in Helsinki in 2007. ECHA employs already 500 people, and an increase to 600 is expected. It is important to realize that this number means an addition to those already employed by the respective national agencies of the mem- 
ber states of the EU. The implementation of the REACH legislation has meant a gigantic effort for the business firms concerned. The well-known German chemical producer BASF has provided for this purpose an amount of 250 million euros. ${ }^{1}$

Another problem with the power of the respective agencies not to admit the use of pharmaceutical drugs because of negative side-effects though they have a positive influence on the specific ailment is the following. This policy prevents the suffering patients to decide to use of the helpful drugs in full knowledge of the negative side-effects. Moreover, the high costs connected with the evaluation may prevent the development of new important drugs. Many small innovative companies are already unable to bear these expenses. As a consequence they have either to license or to sell their invention to big businesses, or they are acquired themselves by them.

The problems for the rule of law are clearly illustrated by the perversity of tax laws. Everybody enjoying some different kinds of properties and income sources is obliged to witness by his signature under his wealth and income tax declarations their completeness and compliance with the full truth. And this despite the fact that even his tax consultant is scarcely able or even unable to know all relevant articles of the laws and decisions of courts.

The increasing number of tax consultants is highly indicative for this development. (See Figure 8 for Germany). Similarly, it would be interesting to know to what extent citizens' freely disposable time is reduced by the same development. The same questions about time and resources spent can be asked for business firms, tax consultants and the administration of the state. And though the situation is especially bad in Germany, the developments in other nations have been similar, as the author can even testify for Switzerland.

But in spite of this situation it seems impossible in countries like Germany to simplify tax laws. A well-designed proposal by the tax specialist and former judge at the Federal Constitutional Court, Prof. Kirchhof (2011), to radically simplify the body of tax

${ }^{1}$ I owe this information to Dr. Christoph Bauer, who formerly worked on these problems for the pharmaceutical firm Novartis. 
FIGURE 8

INCREASE OF THE NUMBER OF TAX CONSULTANTS IN GERMANY, 1961-2010

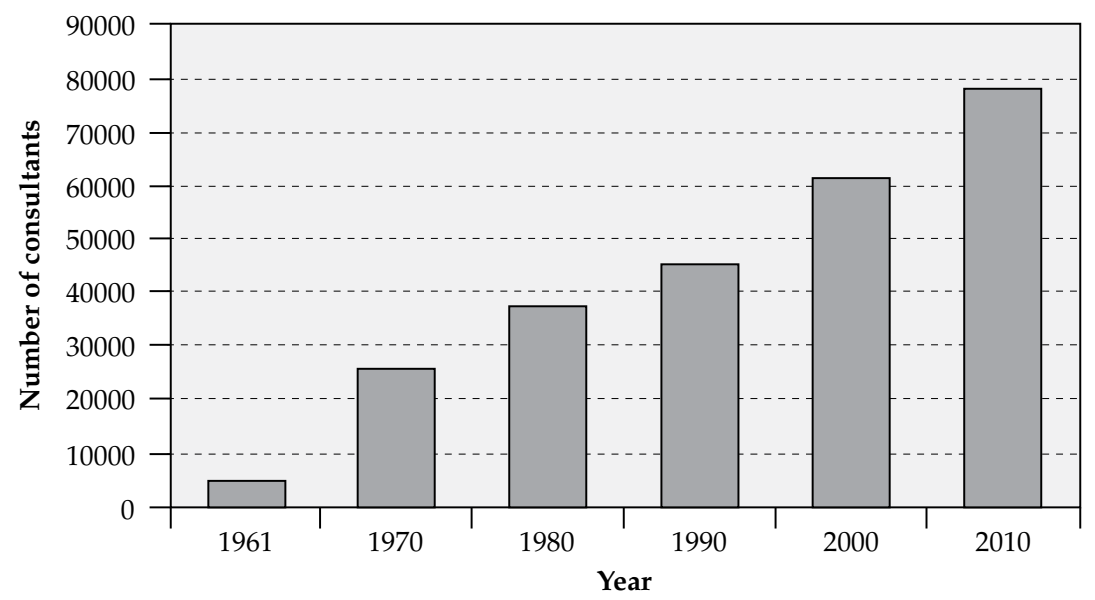

Source: NWB Steuerberater Magazin: Steuer Extra-Ermittlung auf Datenbasis des Statistischen Bundesamtes mit Stand 1.3.2010.

law was met with silence by all parties of the Bundestag (the lower house of parliament). The reasons for such policies are probably twofold: First, benefits and loopholes for special interests have to be hidden from the eyes of voters. Second, with the high level of taxes some exceptions have to be granted to prevent an earlier breakdown of economic growth. For a simplification of the tax system would mean the removal of all exceptions which usually prefer special interest groups and are thus resisted vehemently by those benefiting from them. All this is veiled with slogans of «equality of living conditions», "social justice», and special aims like helping the environment by specific subsidies etc.

Another important field of regulation is scarcely perceived by the population. Since the introduction of compulsary schooling the state is normally running schools and universities in most countries. But this reduces or prevents the beneficial influences of competition, especially in countries where the respective systems and the obligatory rules and standards are highly centralized. The reasons given for this system are the following: Every child should have the same chances, and this would not be possible 
with private schools for poorer people, who could not afford the expenses. Also, the standards of education should be the same everywhere, so that parents and their children would find the same conditions after moving to another place. The first of these arguments has been rejected by Milton Friedman by proposing decades ago the issue of vouchers to all parents, financed by the government. A realization of this proposal would also allow children from low income families to attend private schools, and presumably rises the level of education in public schools by competition. The second argument loses much of its force because of the question: how good are unified standards if they are of a low level, as is now the case in many schools run by the government in many states?

As dangerous as the rising flood of regulations is not only the breaking of promises and of treaties among states, but also their tendency to question the validity of contracts among private citizens, firms and other organizations, or even to invalidate them. The numerous changes of laws and administrative orders not well adapted to practical needs is leading to a flood of complaints at the courts.

We have already mentioned the one-sided change of pension promises by governments. In the European Monetary Union the rules asking for a limitation of government deficits and debts to 3 and $60 \%$ of Gross Domestic Product (GDP) have not been followed by France and Germany already after a few years. But meanwhile much worse events have happened: Not only the article in the Maastricht and Lisbon Treaties forbidding the bailout of bankrupt members by other members and the European Union has been broken several times since 2010, but the European Central Bank (ECB) has also violated the rules contained in these treaties not to buy the debts of about bankrupt governments and banks. And during the debt crisis of Cyprus in 2013 governments have not shied away from directly confiscating bank deposits which are higher than 100000 euros. Though this is certainly better than to ask the taxpayers of other countries to carry the burden of the mismanagement by banks, since the depositors could have watched the soundness of their banks more carefully before, this raises another question. How can individuals protect themselves 
against such measures at a time when they are not allowed to carry more than 10000 euros in banknotes across national borders? How can citizens after such events have any longer trust in the rule of law and the protection of their freedom and wealth against the despotism of rulers?

IV

\section{THE FINANCIAL REPRESSION OF CITIZENS}

Since the beginning of the last financial crisis in $2007 / 08$, followed by government debt crises, leading central banks have reacted, led by the US Federal Reserve System (Fed), by reducing interest rates to nearly $0 \%$. And governments, who had increased their debts already substantially before the beginning of the crisis, not surprisingly, by assisting several of the national banks threatened by bankruptcy, entered an even more precarious financial situation (Figure 3). Indeed, several Southern nations in the Euro Zone were only saved from government bankruptcy by billions of euros in help from the other member states (although this had been forbidden by the Maastricht Treaty) and the International Monetary Fund (IMF). Besides, the ECB granted help by softening conditions for credits, buying government bonds and allowing Southern Central Bank members of the European Monetary System to pile up huge transfer obligations (Target 2 balances) with it (Sinn, 2013). The first of these countries facing bankruptcy was Greece, which is looking back to a long history of bankruptcies since the $19^{\text {th }}$ century. But instead of allowing open bankruptcy again, it received dramatic and escalating financial help, and a veiled bankruptcy was allowed by forcing private creditors into writing off a significant part of their claims.

But what do these events mean for the savings of individuals and their pension funds, even in nations not yet threatened by government bankruptcies? As a matter of fact these events led to a creeping confiscation especially for the poorer part of the population (Figure 9).

As can be seen, the real earnings from assets bearing short-term interest have become negative for most countries during the last 


\section{FIGURE 9}

REAL SHORT-TERM INTEREST RATES IN SEVEN DEVELOPED COUNTRIES, 2008-2012

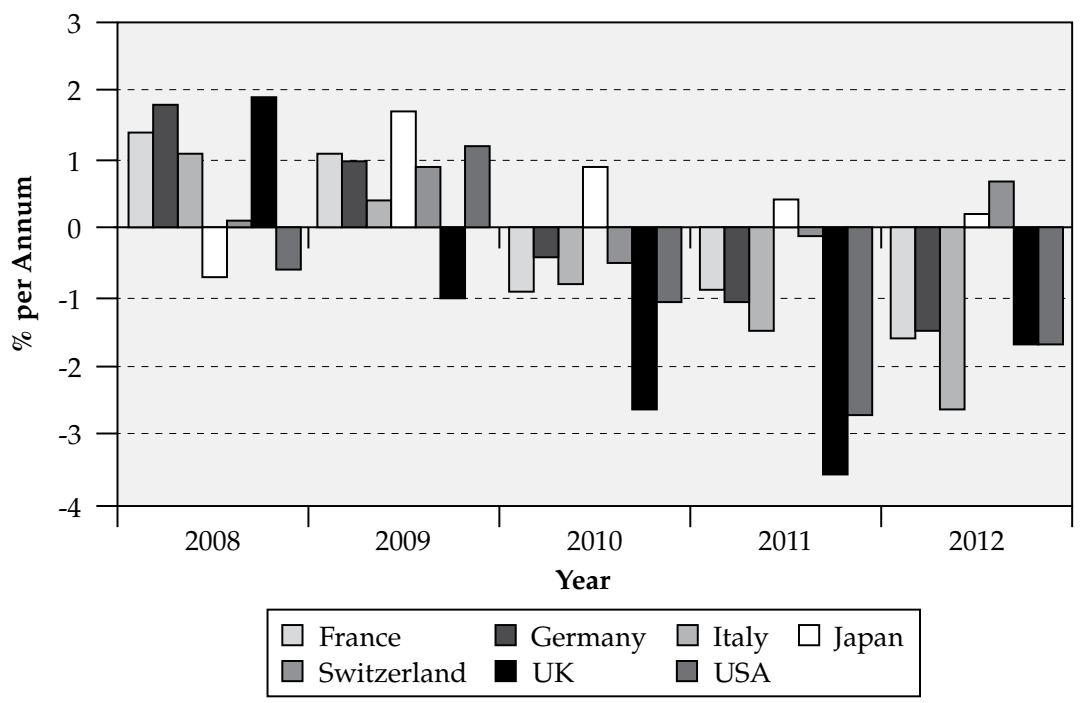

Source: OECD Economic Outlook 92, November 2012.

years. An exception is Japan because of its deflation and also Switzerland in 2012. But these are only gross earnings, namely nominal interest rates minus the rise of the consumer price index. Things are looking worse, if the taxes on nominal earnings are taken into account. For real long-term interest rates the picture seems to look more favorable. Here only Switzerland, the UK and the USA show negative real gross rates during 2011 and 2012. But to get some impression of the net real long-term interest earnings after taxes, I have deducted a 35\% tax on nominal interest earnings (Figure 10). In this case the earnings in all countries become negative in 2008, and for four of the seven in 2011 and 2012. It is important to realize that not only private individuals, but also insurance firms and pension funds (which have historically also often been forced to buy government debt at low interest rates) are suffering from the low interest rates brought about by the policies of central banks. 
FIGURE 10

REAL LONG-TERM INTEREST RATES IN SEVEN COUNTRIES WITH 35\%, TAX ON NOMINAL EARNINGS

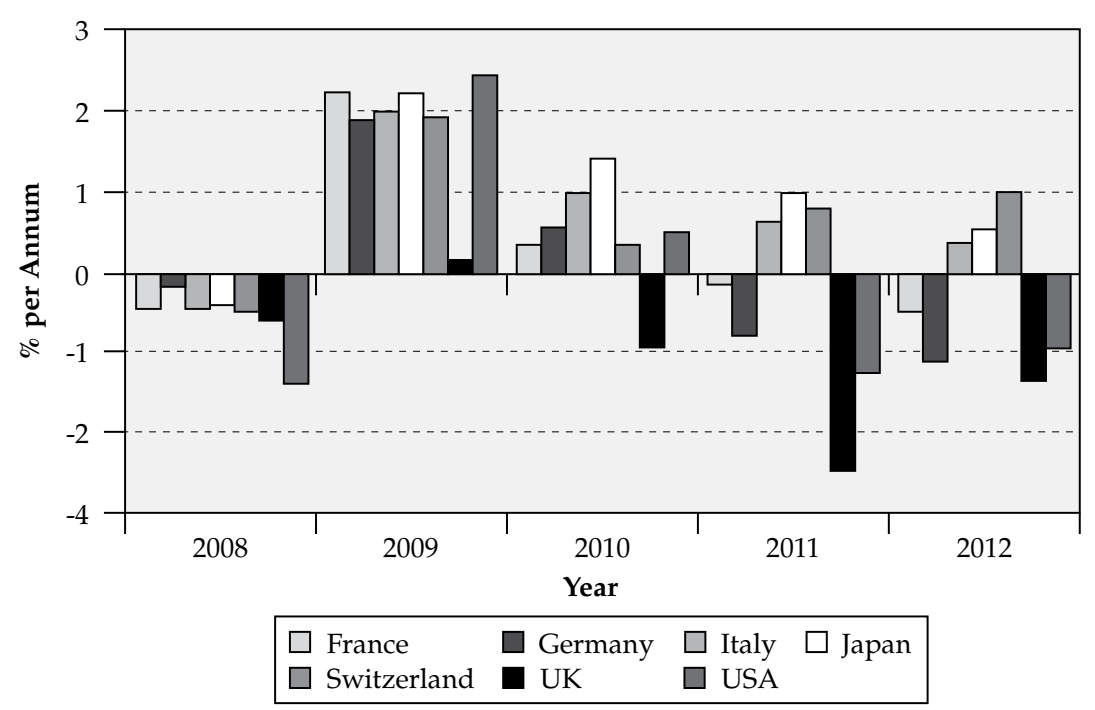

Source: OECD Economic Outlook 92, November 2012.

Moreover, as shown by Reinhart and Rogoff (2011) such events are not an exception limited to the financial and government debt crisis since 2008. They explain:

It is worth noting that the real ex post interest rate on public debt (appropriately weighted by the type of debt instrument) was negative for US debt for 25 percent of the years during 1945-80, while the comparable share for the United Kingdom was nearly 50 percent, ...(p. 31 f.).

Though it has been shown meanwhile that Reinhart and Rogoff made a mistake in their calculations, it is still true that growth rates are negatively influenced by high burdens of debt. 


\section{$\mathrm{V}$ \\ DRUGS, TERRORISM, «MONEY-LAUNDERING» AND THE TRANSPARENT SUBJECT}

Since long years all citizens are already suspected of «moneylaundering» whenever they do not declare to the border controls that they are carrying more than 10000 euros or Swiss francs with them. The US regulations are even more rigorous. And if they declare that they carry, let's say 15000 euros across the border, the usual burden of proof is reversed. For they have to prove that the money is their legal property and has been legally acquired. If they cannot prove it or if they did not declare the amount, their property is confiscated.

To carry your own money with you had not been a crime in earlier decades. It was artificially made a crime following the pressure by the USA, since American authorities were not able to win the "war» against drug providers, which they had initiated by forbidding the production, sale and use of drugs.

As a consequence of making the production and use of drugs a crime, the prices of drugs went up substantially and their production and distribution became a flourishing business. The high prices led to secondary criminality by drug consumers who had now to try to get enough money to pay for them. Moreover, since it became rewarding for farmers to produce drugs, several nations trying to suppress the production with the financial and military help of the USA, now entered a long-lasting fight against their own farmers and the "drug barons» supporting them and smuggling their product to the countries with the highest demand.

Soon it turned out that the laws against «money laundering» did not help to win the "war». Quite the contrary: Several countries like Columbia, Bolivia and Afghanistan were soon at least partly dominated by the «drug barons», who were making big profits because of the high prices. At the moment the drug war is raging in Mexico, where the number of deaths because of the fights of drug barons with each other and the police has been steadily increasing during the last years. As a consequence private citizens are already active in forming militias to fight these crimes. Near Acapulco hundreds belonging to a private militia have 
recently occupied and isolated a small town. Eighteen suspects were arrested, among them the local chief of the police suspected of close relationships with the criminal cartels (reported by the Neue Zürcher Zeitung, the leading Swiss newspaper, on March 30, 2013).

On the other side of the globe the Taliban terrorists in Afghanistan are financing their activities against the NATO armies in this country mainly with the help of selling drugs.

But in spite of this contradiction with its own efforts to stabilize Afghanistan, the USA has taken Islamist terrorism after the attack on the World Trade Center in New York as another pretext to strengthen not only the laws on «money-laundering» against all citizens, but also to introduce strict bodily controls of all persons crossing its borders. And during the last years these controls against «money-laundering» have been more and more used for tax purposes.

These are disquieting attacks on the freedom of the majority of citizens who have nothing to do with the drug business, terrorism and are regularly paying their taxes. And all these measures have been taken though banknotes are the only legal tender and though their value as a means of payment depends partly on their nature as a bearer's note. Moreover, banknotes of relatively stable currencies are not only a last safeguard against confiscation of bank deposits like in Cyprus in 1913, but also against high inflations in many nations. But the measures against paying with banknotes are getting more and more extensive. It seems that presently (2013) France and Italy are considering to forbid the use of cash for payments higher than 1000 euros. And recently (February 2013) the Swiss government has proposed to forbid payments in banknotes of more than 100000 Swiss francs domestically. Moreover, rumors are circulating (2013) that the USA are exerting pressure on Swiss authorities to abolish the 1000 franc banknote. All this would be quite consistent with US policies to force all banks having business with the USA to become a kind of police for its tax authorities, obliged to report all holdings with them of American residents (by the so-called Fatca legislation). This means again that all people residing in the USA with foreign bank accounts are now suspected of tax fraud. 
Several Swiss banks have already decided not to accept any deposits of people living in the USA. This is of special concern to Swiss citizens living in America who need a Swiss account for ordinary payments they have still to make and are receiving in Switzerland.

The war against drugs has been without any success until now. It has only brought about the rise of criminal gangs, secondary criminality and the possible take-over of power by drug barons in several countries. As a consequence the criminalization of the production, distribution and use of drugs should be abolished. The consequent fall of prices would destroy the huge profits of drug barons, reduce secondary criminality and the murderous fights among drug gangs and police (who are also partly corrupted by receiving bribes) in several nations. At the same time, it has to be doubted that the number of drug addicted people would much increase because of lower prices. For addiction remains the same whatever the prices. The only problem might be that younger people were more often attracted to experiment with their use. But this problem should be taken care of by a better education drastically pointing out the dangers of drugs.

With the legalization of drugs all laws and regulations on «money laundering» and the use of cash should be given up. For the successes in fighting terrorism compared to the expenses of these policies seem to be negligible. The same is probably true for the strict border controls. Presently the Department of Homeland Security in the USA is costing about 40 billion dollar annually (Presidential Bureau of the Budget).

But the really more important costs are not measurable, namely the loss of freedom citizens experience who are suffering from all these measures. The extension of the rules against «moneylaundering» to control everybody for suspected drug business, terrorist activities and tax evasion is putting all citizens under suspicion and is leading in time to absolute transparency of people for government agencies, including police, secret services and tax authorities which cannot be adequately controlled by the legislature. In this way citizens are turned into subjects who are not willing to face the risk of standing up against problematic or illegal acts by government authorities because they are afraid 
that these agencies may know some trivial or unintentional transgression of laws or orders by themselves.

\section{VI \\ CONTROL OF PRIVATE INFORMATION FLOWS UNDER THE PRETEXT OF PROTECTING THE PEOPLE OR THE STATE}

The privacy of citizens is more and more threatened by government access to information covering all their private messages. In some cases this may be illegally done by secret services which are often transgressing their rights granted by law. ${ }^{2}$ Even in Switzerland it was revealed in the late 1980s that the federal public prosecution acting for the Staatsschutz (the agency responsible for protecting the state) had illegally gathered information about 900000 out of about 7 million Swiss inhabitants. This led to a public outcry, so that this information was obliterated and the rights of the agency severely restricted. But in recent years governments are even granting legal rights not only to secret services but also to the police to watch all private contacts and (or) information flows. At the moment the Swiss secret service is «only» allowed to register all contacts by phone, computer and mail among persons and to store them for one year. The contents

2 After this paper had been completed, the American Edward Snowdon revealed in the beginning of June 2013 the all-encompassing world-wide spy activities of the American National Security Agency without adequate Congressional or judicial control. Domestic and foreign telephone and internet contacts between private people, business firms, private organizations and foreign government agencies have been looked into at the discretion of this agency, partly with the help of such telephone firms as Verizon, ATT, Sprint Nextel. With the help of a program called Prism the NSA was able to directly open the servers of Microsoft, Google, Yahoo, Facebook, Youtube, Skype and Apple. It remains to be seen whether the following international outcry persists or even spreads. But it seems clear that these events are violating the Fourth Amendment of 1791 to the US Constitution: «The right of the people to be secure in their persons, houses, papers, and effects, against unreasonable searches and seizures, shall not be violated, and no warrants shall issue, but upon probable cause, supported by oath or affirmation, and particularly describing the place to be searched, and the persons or things to be seized.» 
of the information are, however, not stored. But now (March 2013) the government is proposing to legalize the opening of mail, the listening to phone conversations and the spying out of computers by the Nachrichtendienst des Bundes (the Federal Information Service). This, however, would be «only allowed» if one out of five dangers were present: terrorism, foreign espionage, assembling of dangerous weapons, and threatening attacks on communication, energy and other critical structures. Moreover, first the Federal Administrative Court (Bundesverwaltungsgericht) would have to agree to corresponding measures, then the Minister of Defense and finally a group of three federal ministers. On the other hand, no limits are planned for espionage in foreign countries, and the federal government «can use the services of the Federal Information Service in other specific situations for safeguarding other important interests of the country.» According to the proposal this includes «the protection of the Swiss workplace, its economy and financial institutions.» (Neue Zürcher Zeitung, March 9, 2013) It has to be seen whether this bill has indeed a chance to be approved by the federal parliament. But there it is quite possible that its politicians will accept the proposal without many changes. For recently the parliament has agreed that the federal agency responsible for the gathering of information on money-laundering will be allowed to pass on this information to foreign agencies (Neue Zuercher Zeitung, March 22, 2013). Similarly, the parliament has passed a motion (March 14, 2013) to allow the police to get information from the data bank obtained by assembling vital information for providing new passports. And this though it had been promised not to use it for purposes of the police when the extension of the information required for the new set of passports had been introduced. Given that such developments are possible in peaceful and neutral Switzerland it should not come as a surprise that the secret services of countries like the USA have much earlier begun to spy out their own compatriots without the limits still observed in this small country with a strongly developed direct democracy.

A much more subtle suppression of the free flow of information or free speech is hidden under the label of so-called "political correctness». This implies that certain words like Negro, Eskimo 
and (Red) Indians are no longer socially correct. They have to be substituted for instance by African American, Inuit or Native American. Often this is bordering the ridiculous. For Negro means just black in Latin. And are whites whose ancestors have come to the USA before the American Revolution no longer natives there? In Germany expressions like «Lehrling» (apprentice, verbally translated: Somebody who has still to be instructed) are considered inappropriate and have been substituted by «Anzulernender» which ironically has about the same meaning. But things are getting worse. In the German newspaper «Die Welt» (31.1.2013) a lady, Kathrin Spoerr, is reporting, that an educator at a protestant kindergarten was rebuked by her superior, a priest, for using the expression Zigeuner instead of Sinti and Roma, which is now the correct expression for gypsy in German, in a play organized with the children.

In certain countries liked Germany and Switzerland it is now forbidden by law to deny in public historical events like the holocaust, the mass murder of Jews committed by the Nazis, or the mass killings of Armenians in the Osman Empire during the World War I. Moreover, the use of Nazi symbols like the Swastika, though it is a very old symbol for instance in India, is defined as a crime.

The former is a severe violation of the right of free speech, the latter just ridiculous. If certain uneducated people deny that the holocaust happened, let them just reveal their stupidity. Whereas penalizing their assertions may even motivate some people to suspect that they are containing some truth.

\section{VII}

THE ABOLISHMENT OF HABEAS CORPUS AND THE INCARCERATION AND KILLING OF PEOPLE WITHOUT DUE PROCESS OF LAW

It should be clear to everybody that wars are the greatest threat to human liberty. This begins already during peace in countries where all young males are drafted to «serve» in the military, sometimes up to two years. From a radical point of view one could 
describe this as a kind of time-limited slavery. And indeed, many misuses of their power to command by sergeants and officers have emerged. Aggressive wars which are not justified by purposes of defense against other nations have brought death and misery not only to the members of fighting armies, but also to millions of civilians.

In recent years such wars have been initiated by President George W. Bush under dubious pretexts. He fought a war against Iraq under Dictator Saddam Hussein and one against Afghanistan dominated by the radical Islamic Taliban after the attack on the World Trade Center by al-Qaeda on November 7, 2001 (7/ 11). Whereas the latter may have been justified by the close relationships of the Taliban with al-Qaeda, and thus has been supported by NATO, this was certainly not true for Iraq. The dictator was the last to allow an erosion of his abject power by Islamists. But Bush asserted, perhaps even against better knowledge, that he was involved with al-Qaeda. The results of this victorious war are catastrophic after the withdrawal of most American and British forces. Apart from a murderous civil war, especially between Shiites and Sunnites, al-Qaeda is now more influential in Iraq than it could ever have been under Saddam Hussein. And in Afghanistan, when NATO forces are planned to be withdrawn from the country, there is a grave danger that the Taliban may return to or at least participate in power. In fact, this could be foreseen by any knowledgeable observer.

But the secondary consequences of these wars and the general «war on terrorism» declared by President Bush and still maintained by President Obama are much more dangerous for the freedom of citizens in developed democracies. I have already mentioned the increased border controls and the strengthening of laws against money-laundering. But far worse, with the beginning of the war all prisoners suspected of terrorism were brought to Guantanamo, an American base in Cuba, with the purpose to keep them outside the jurisdiction of American courts. Here they were tortured with water-boarding (simulated drowning) and other procedures clearly violating the Geneva Convention protecting prisoners of war. Obama promised to end the prison camp at Guantanamo when be became President, but has still not succeeded to do so after four 
years in office. This is caused by resistance in the US Congress, who prohibited the Administration to pay for the transfer of prisoners to the American mainland.

Meanwhile at Guantanamo a special military court has begun legal proceedings against five leading terrorists in the end of 2012. But the court decided that any information about the arrest, the place where they were kept before being brought to Guantanamo and about the special interrogation methods like waterboarding should be suppressed during the transmissions of the court proceedings into the room for spectators.

This news corresponds well with other information concerning the violation of human rights by US agencies. On December 13, 2012 the European Court in Strasbourg decided that Macedonia had violated the rights of kidnapping victim Khaled al-Masri and had to pay him a compensation in the amount of 60000 euros. The government of Macedonia were responsible for the torture and maltreatment of this German-Lebanese citizen on its territory and also his extradition to the US CIA. The court saw in the maltreatment of the victim on the airport of Skopje a kind of torture.

A similar case was decided by the Court of Appeal in Milan on January 8, 2013. In this case the court condemned the former head of the Italian Secret Service, Nicolo Pollari, and his Vice, Marco Mancini, to 10 and 9 years in prison, because they had collaborated in the seduction of the Egyptian Imam Abu Omar by the American CIA in Milan on February 17, 2003. The Court of Appeal also condemned three other members of the Italian Secret Service and two dozen agents of the CIA in absentia to prison sentences. Moreover, it granted the former Imam a compensation in the amount of one million euros.

Another decision of the European Court in Strasbourg throws more light on the practices of the CIA in kidnapping suspected but sometimes innocuous victims. In this case the court decided to begin public legal proceedings concerning an alleged former secret and illegal CIA prison in Northeast Poland. The proceedings relate to the Saudi-Arabian Abderrahim an-Nashiri who complains to have been imprisoned and tortured in Poland for some time. 
On March 2, 2013 the British newspaper Guardian and the BBC reported that the USA had helped Iraq to introduce military prisons during the last decade, where people were tortured. Two Americans had played prominent roles in doing so, who had already participated in the "dirty wars» in Central America in the 1980s. They had reported directly to the boss of the Pentagon, Donald Rumsfeld, and to general David Petraeus, respectively. If these British inquiries should prove true this would throw a suspicion on Rumsfeld and Petraeus. Until now the USA have always asserted that well-known cases of maltreatment, for instance in the prison Abu Ghraib, had been caused by abnormal behavior of single soldiers

A further characteristic of American "war on terror» is the expansion by Obama of George W. Bush's drone war, that is of unmanned airplanes to commit targeted assassinations. This may have been warranted to a certain degree as long as it is selectively directed against high-ranking enemies because of saving own lives and limiting collateral damages. But it is exactly this higher selectivity which is tempting to extend the use of drones to areas of lesser threat, even at the risk that many innocent civilians are killed. However, even if it is admitted that the first attacks were justified to get rid of very dangerous high-level al Qaeda terrorists in Pakistan, who were trying to strike the United States, this is no longer true presently (in April 2013). As Ivan Eland (2013), member of the Independent Institute, put it:

now American drone attacks are mainly striking mid-to low-level Islamist fighters in Pakistan and Yemen who focus their attacks on the Pakistani and Yemeni governments. As the attempted Times Square and underwear bombings show, the U.S. now has new enemies in the Pakistani Taliban and al Qaeda in the Arabian Peninsula, respectively. The same blowback may happen in Somalia and other countries where drones are being used to target would-be terrorists. ...

Even more problematical than the blowback is the dubious constitutionality of the expanded drone campaign. ...The worst problem is Obama's killing of Americans anywhere anytime using secret criteria.... 
The major problem with Obama's expanded drone war are that he is stretching the terms «immediate threat» beyond recognition to justify dubious presidential action and that he is now targeting region al Qaeda affiliates in Pakistan, Yemen and Somalia.- all of which had no role in the $9 / 11$ strikes and which focus their attacks mainly against local governments. This expanded war is congressionally unauthorized, and so it is illegal and unconstitutional to kill anyone in these countries - Americans or foreign people.

It is thus not surprising that Congress has taken up the problem. As became known later, the legal service of the Department of Justice had analyzed in 2011 the targeted killing of an American in the process of fighting terrorism. This they did mainly because they intended to present to certain members of Congressional Committees the arguments of the Department. Now the NBC has acquired a 16 page memorandum in which the analysis is sketched. This occurred at the same time when eleven Senators of both parties tried to get information about the original analysis.

According to the memorandum four conditions must be fulfilled to legalize the assassination of American citizens when fighting terrorism:

1. The respective suspects are executing high operational functions in al Qaeda or affiliated groups;

2. An arrest must be impossible without doubt;

3. The military strike against suspects must be in accordance with the international rules of war and humanitarian law;

4. A high official of the government must conclude that the activities of the suspect pose an imminent danger to the USA.

Here the broad interpretation of «imminent danger» is especially disturbing. Already the constant and purposeful preparation of an attack is defined as such. Moreover, it is assumed that the USA are involved in a war against a non-state enemy in accordance with humanitarian international law. Finally, the attack against the enemy can also take place within the territory 
of a third nation, if this state could or would not take adequate action against the enemy on its territory.

It is also important that the Washington discussion refers only to the killing of American citizens and that the decision whether an imminent danger is present is at the discretion of the administration not controlled by the independent judiciary.

Considering the facts discussed above, we should not be surprised to read the following statement by Jonathan Turley, professor of law at George Washington University:

An authoritarian nation is defined not just by the use of authoritarian powers, but by the ability to use them. If a president can take away your freedom or your life on his own authority, all rights become little more than a discretionary grant subject to executive will.... Since $9 / 11$, we have created the very government with sweeping and largely unchecked powers resting on the hope that they will be used wisely.

\section{BIBLIOGRAPHICAL REFERENCES}

Arnold, J. (2008): «Do Tax Structures Affect Aggregate Economic Growth? Empirical Evidence from a Panel of OECD countries». Paris: OECD Economics Department Working Paper 643.

Baum, A.; Westrhal, C. and Pother, P. (2012): «Debt and Growth. New Evidence from the Euro Area». European Central Bank: Working Paper Series 1450, July.

BERGH, A. and KarLSSON, M. (2010): «Government Size and Growth. Accounting for Economic Freedom and Globalization». Public Choice 142 (1-2), 195-213.

Bernholz, P. (1986): «Growth of Government, Economic Growth and Individual Freedom». Journal of Institutional Economics (Zeitschrift für die gesamte Staatswissenschaft) 142, 661683.

BörsCh-Supan, A.H. (2012): «Policy Mixes in the Current European Pension Reform Process». CESifo DICE Report 10 (4), 9-15. 
Eland, I. (2013): «Obama's Drone War Could Legally Kill Americans But Not Anywhere». Posted February 18. http:// www.independent.org/newsroom/article.asp?id=3553

FRIEDMAN, M. (1955): «The Role of Government in Education». Robert Solo (Hrsgb.): Economics and the Public Interest, I 1955. New Jersey: Rutgers College.

GATTUSO, J.L. (2013): «REINS Act of 2013»: Promoting Jobs, Growth and Competitiveness. Testimony before The Subcommitty on Regulatory Reform, Commercial and Antitrust Law. Committee on the Judiciary. United States House of Representatives. http://www.heritage.org/research/testimony/ reins-act-of-2013.

Hölderlin, F. (1946): Hyperion. Ulm: Aegis-Verlag.

IW (2012): Deutschland in Zahlen. Kölner Institut der deutschen Wirtschaft.

KornaI, J. (1971): Anti-Equilibrium. Amsterdam: North Holland. KirchHOF, P. (2011): Ein einfaches Bundessteuergesetzbuch politische Notwendigkeit oder akademischer Traum? Zur Debatte (Themen der Katholischen Akademie Bayern) 8/11, 9-12.

LIPFORD, Y.W. and YANDLE, B. (2012): «Tax Payers and Tax Spenders: Does a Zero Tax Price Matter?» Independent Review 16(4), $517-531$.

Reinhart, C.M. and Rogoff, K.S. (2011): «A Decade of Debt. Policy Analysis» in International Economics 95. Washington, D.C.: Peterson Institute of International Economics (September).

ROMER, C.D. and ROMER, D.H. (2001): «The Macroeconomic Effects of Tax Changes: Estimates Based on a New Measure of Fiscal Shocks». American Economic Review.

SINN, H.-W. (2004): Ist Deutschland noch zu retten? München: Econ.

- (2012): Die Target Falle. Gefahren für unser Geld und unsere Kinder. München: Karl Hanser.

TANZI, V. and SchukneCht, L. (2000): Public Spending in the $20^{\text {th }}$ Century. Cambridge: Cambridge University Press.

Tocqueville, A. DE (1945): Democracy in America. 2 vols. New York; Vintage Books. 
WeEDE, E. (1991): «The Impact of State Power on Growth Rates in OECD Countries». Quality and Quantity 25, 421-438.

- (2012): Freiheit und Verantwortung, Aufstieg und Niedergang. Tübingen: Mohr Siebeck. 